\title{
GAMING PRACTICES AND TECHNOLOGIES IN EDUCATION: THEIR EDUCATIONAL POTENTIAL, LIMITATIONS AND PROBLEMS IN THE WORLD-OF-WORK AND WORLD-OF-PLAY CONTEXT
}

PRÁTICA E TECNOLOGIA DE JOGOS NA EDUCAÇÃO: SUAS POTENCIALIDADES EDUCACIONAIS, LIMITAÇÕES E PROBLEMAS NO CONTEXTO DO MUNDO-DO-TRABALHO E DO MUNDO-DO-JOGO

\section{PRÁCTICAS Y TECNOLOGÍAS DE JUEGOS EN LA EDUCACIÓN: SU POTENCIAL EDUCATIVO, LIMITACIONES Y PROBLEMAS EN EL CONTEXTO DEL MUNDO-DEL-TRABAJO Y EL MUNDO-DEL- JUEGO}

\begin{abstract}
This article highlights and discusses potential opportunities, limitations and problems related to using games and game technologies (such as gamification) in education. For the purpose of the study, games are seen ontologically as conditional realities. The world-of-work and world-ofplay concept, which stems from the ideas of social phenomenology about lifeworld and multiple realities, forms a methodological basis for the analysis and differentiation between game and nongame activities, thus underlying the scientific novelty of our study. The following conclusions were inferred: By turning learning into a game we may prompt students to perceive the world-of-work (duties, responsibilities) as the world-of-play (desires, freedom); then, either the school will lose its socializing role in preparing students for life, which is a world of work and commitments rather than a world of game, or students will become bored with the game that will lose its appeal (or suggest manipulations). Thus, despite all its advantages, game-based and gamified education should not be seen as a panacea.
\end{abstract}

Keywords: Game. Gamification. Ontology. Pedagogy. Philosophy of education.

Resumo: Este artigo disserta e discute sobre as potenciais possibilidades, limitações e problemas relacionados a uso de jogos e tecnologias de jogo (tais como gamificação) na educação. Para tanto, consideramos ontologicamente os jogos como realidades condicionais. O conceito de Mundo-doTrabalho e Mundo-do-Jogo, desenvolvido pelas ideias da fenomenologia social sobre lifeworld e Multiple Realities, é uma base metodológica para análise e diferenciação de atividades lúdicas e não lúdicas, que constitui-se como a novidade científica deste artigo. Na nossa pesquisa chegamos às seguintes conclusões: a transformação da aprendizagem em atividade lúdica fará com que os alunos

\footnotetext{
${ }^{1}$ Ural Federal University. Ekaterinburg, Russia.
} 
se acostumem a perceber o Mundo-do-Trabalho (dever, compulsão) como uma analogia ao Mundodo-jogo (desejo, liberdade) e a escola perderá seu papel de agente de socialização que faz a preparação para vida que na maioria doa casos atua como o Mundo-do-Trabalho-e-Tráfego e não como o Mundo-do-Jogo. Ou então os alunos se cansarão de jogar, e os jogos perderão o seu atrativo (inclusive por suspeitarem dessa tecnologia manipulativa). Como resultado, concluímos que a educação baseada em jogos, com todas as suas vantagens, não deve ser tomada como uma panaceia.

Palavras-chave: Jogo. Gamificação. Ontologia. Pedagogia. Filosofia da educação.

Resumen: En el presente artículo discuten las posibilidades, limitaciones y problemas potenciales relacionados con el uso de tecnologías lúdicas (tales como la ludificación/ gamificación) en la educación. Para lograr tal objetivo, contemplamos los juegos desde el punto de vista ontológico en calidad de realidades condicionales. La concepción del Mundo-del-trabajo y el Mundo-del-juego, desarrollada a partir de las ideas de la fenomenología sobre el lifeworld y las Multiple Realities, son la base metodológica cuya aplicación en el análisis y la diferenciación de las formas lúdicas y no lúdicas de las actividades constituye la novedad de este artículo. Durante el estudio llegamos a las siguientes conclusiones: el problema con la transformación de la educación en una actividad lúdica es que los participantes se acostumbran a percibir el Mundo-del-trabajo (deudas, presiones) de manera análoga al Mundo-del-juego (deseos, libertades) y la escuela pierde su rol como agente de socialización que prepara para la vida, la cual llega frecuentemente como un Mundo-del-trabajo-yde-cuidados en lugar de un Mundo-del-juego; o el alumno se harta de las actividades lúdicas y pierden todo el atractivo (incluyendo la sospecha de que estas últimas están viciadas con técnicas de manipulación). En conclusión, llegamos a la compresión de que la educación basada en juegos, a pesar de todas sus virtudes, no debe ser asumida como una panacea.

Palabras clave: Juego. Gamificación. Ludificación. Ontología. Pedagogía. Filosofía de la educación.

\section{INTRODUCTION}

The game as modeling of situations (the war game), as a problem-solving technique, as an approach to scientific and philosophical discussions (Plato's dialogues; debates between nominalists and realists resorting to humorous and facetious examples in their arguments, etc.) as well as a method to get people engaged in a certain, seemingly boring activity by turning it into fun has been used since ancient times. It is connected with "one of the main aspects of play, which is the simple fact that it is enjoyable in itself. Regardless of whether it decreases anxiety or increases competence, play is fun." (CSIKSZENTMIHALYI, 1975/2014, p. 136). 
The Fun ${ }^{2}$ is the key and pretty much the most important parameter responsible for fulfilling the main purpose of the game, namely, the increased engagement, which is especially significant and relevant in learning activities.

The capability of games to cause a flow state has been intuitively realized and used in pedagogy for a long time; however, digitalization of education made education specialists look at new opportunities provided by the digital environment. The gamification technology was one of them. Gamification came into being as a response to the challenges of the fifth (after advents of speech, writing, printing, radio and television) information revolution ${ }^{3}$ with the computer and the Internet representing its iconic attributes.

The gamification technology has borrowed a lot from games (primarily, from digital and mixed-reality games), including their opportunities and limitations, which are addressed in our article. There are different approaches to gamification, but all of them are rooted in the definitions offered by two groups of scholars: S. Deterding et al. and K. Kapp (and his followers). In our article, we will compare both approaches (the narrow one and the broad one) and will investigate the outcomes of their application.

Also, the vector has been changed in studies of digital games. While initially scholarly and popular literature focused on the most negative aspects of the above games - incitement to violence, inadequate behavior, and addiction - later on, these games were studied in the context of their educational capabilities. We explore these educational capabilities of games (not limited to digital games) by the example of video games, live Action Role-Playing Game and Alternate Reality Games.

In our essay, we will focus on the ontological aspect of games representing conditional realities (hence, three main types of games: digital games, real-life games and mixed-reality games) and will look at them from the perspective of phenomenology giving birth to the world-of-work and world-of-play antithesis. Note that the world-of-play should not be narrowed down to leisure (or solely to game activities) and the world-of-work should not be limited to work activities. Instead, their differentiation should be based on the following dichotomies: Freedom - Constraint, Want Must. Patterns of this opposition can be found in ancient times. However, the gaming approach,

\footnotetext{
${ }^{2}$ Fun can have different forms. The present-day studies assign the highest rating to Hard Fun (for example, in MMORPGs such as World of Tanks or The Elder Scrolls Online as well as in strategy and shooter games). This is due to the fact that in game, unlike many other activities, the idea of failure is part of its ethos.

${ }^{3}$ Its forerunners were mentioned back in the 1960s - 1970s in works of such renowned philosophers as D. Bell, A. Toffler, H. M. McLuhan, A. Moles, Y. Masuda and others.
} 
being a prerogative of deities ${ }^{4}$ and, thus, being placed above the natural and moral laws; or representing a principle of otherworldly life in ancient Greek, Hindu, Sumerian and other mythologies; or being attributed to a spiritual, elevated and not down-to-earth lifestyle, pursuit of self-perfection and self-actualization in ancient philosophy, cannot be applied to all life realities and situations ${ }^{5}$, at least, as long as the kingdom of necessity and non-freedom retains its positions and a Utopia by Bernard Suits (1978), "where people are engaged only in those activities which they value intrinsically" (p. 166-167), has not yet come.

And although J. McGonigal, following M. Csikszentmihalyi, believes that it is necessary to "reinvent reality to work more like a game" (MCGONIGAL, 2011, p. 16) (for this purpose she identifies 14 Fix), but it is worth considering the limits and consequences of such a reinvent and rethink. In our article, we will try to consider them in the context of education.

\section{GAMES AND LEARNING}

The urge to play is innate to humans. As Huizinga asserts, games are older than culture. Play and learning are inextricably intertwined: People have been learning through play since the dawn of humankind. While playing, children learn to make sense of the world around them and develop social skills. But the obviousness of this fact could not overcome the perception of play/games as the antithesis of learning for a long time. Only after efforts of Renaissance philosophers Tommaso Campanella and François Rabelais, enlighteners Jean-Jacques Rousseau and John Locke, education reformer John Amos Comenius the opposition between play and learning was removed. Friedrich Froebel and Jean Piaget offered a scientific basis for the play and learning relationship. F. Froebel identified didactic aspects of the play activity, while J. Piaget saw play not only as the way children learn and make sense of the world around them, but also as the way to create imaginary worlds. However, the above philosophers and pedagogues focus their attention on play and its role in education of children rather than of adult students. "Game elements in higher and further education came to attention of scholars in the 20th century during implementation of active learning methods" (GILYAZOVA; ZAMOSHCHANSKII, 2020, p. 43).

This trend has increased even more in the 21st century. The contributing factors are: 1) Lifelong learning gaining popularity and requiring most efficient and simple teaching methods; 2)

\footnotetext{
${ }^{4}$ see the description of Krishna's Acts (Lila) as divine play solely for enjoyment, entertainment, and fun.

${ }^{5}$ For example, the thesis that the life of Christ, let alone, his excruciating torments on the cross, was nothing but a game or play-acting devalues them and makes them meaningless.
} 
technology growth cuts across the entertainment and game sectors, thus resulting in penetration of the game component into different areas of life; 3) ICTs availability that allows a large number of participants to be engaged in a game, thus resulting in massification and popularization of gaming; 4) increased interest in training games, as people tend to prefer productive leisure time (BUKHTOYAROV; KOZLOVA, 2018). Not surprisingly, games and education are getting increasingly intertwined in the digital age.

Information and Communication Technologies (ICTs) play an important role in this process. They have experienced rapid technological progress. Their transformation has changed the behavior of all age groups, but their main impact has been on the most recent generations (SHUTALEVA et al., 2019). These new generations, born in and after the 1990s, are named the 'Net Generation' by D. Tapscott; the 'iGeneration' by L. Rosen; the 'platform society' by J. Dijck, T. Poell \& M. de Waal; the 'Generation of the Millennium' by W. Strauss \& N. Howe.

It has become necessary to change education paradigms to fit in the cultural context of the Millennials: the knowledge acquisition in the 'Zuckerberg Galaxy' is different from the knowledge acquisition in the 'Gutenberg Galaxy'. Abundant and easily accessible online information, which, if desired, an individual can receive and perceive on his own, refocuses the education paradigm from transmission of knowledge to generation of this desire. This process involves engagement of the individual rather than acquisition of knowledge and it is the main and distinctive feature of gamebased learning. As Marc Prensky (2005) writes:

'Engage Me or Enrage Me,' these students demand. And believe me, they're enraged. [...] But they all do something engaging. [...] Except in school. And there it is so boring that the kids, used to this other life, just can't stand it. [...] In my view, it's not 'relevance,' that's lacking for this generation, it's engagement (PRENSKY, 2005, p. 62-64).

But there is a problem related to implementation of games in education, which is that teachers are not always ready to change the subject-object paradigm representing the relationship with the audience, being afraid they may lose hold of the audience and control over it. "However, soon it will be necessary to answer new challenges imposed by the current 'game generation', as the competition in the field of education does not leave any chance to rely only on conservative methods." (ALGAVI et al., 2017, p. 68). 


\subsection{DEFINITIONS OF THE TERM 'GAME’}

What is a game? Let's look at the main definitions. Fundamental definition for scholars is Huizinga's definition:

Summing up the formal characteristics of play we might call it a free activity standing quite consciously outside 'ordinary' life as being 'not serious', but at the same time absorbing the player intensely and utterly. It is an activity connected with no material interest, and no profit can be gained by it. It proceeds within its own proper boundaries of time and space according to fixed rules and in an orderly manner. It promotes the formation of social groupings which tend to surround themselves with secrecy and to stress their difference from the common world by disguise or other means (HUIZINGA, 1949, p. 13).

According to K. Kapp (2012), "A game is a system in which players engage in an abstract challenge, defined by rules, interactivity, and feedback, that results in a quantifiable outcome often eliciting an emotional reaction." (p. 7).

Andrey Komissarov (2020), one of the leading Russian educational game practitioners, defines the game as a space of free choice and interaction. This space implies a special play activity and it exists only when its participants accept rules, conventions, and limitations of this space deliberately, responsibly and cheerfully.

Bernard Suits (1978), an authoritative philosopher in the study of games, defines: "Playing a game is the voluntary attempt to overcome unnecessary obstacles" (p. 41).

The definitions given by the above scholars (and many others) implies characteristics typical of any game: Conditionality of events, spatial and temporal boundaries, fixed rules and quantifiable outcome, feedback system, unnecessary obstacles, freedom, voluntary participation, nonexpectation of material utility.

Let us look at the essential elements of a game.

The conditionality of games, while integrating them with other conditional realities (art, media, etc.), sets them apart from the actual reality, preventing any mix-ups (which may happen in real-life games (pranks) where, as distinct from digital games, the borderline with the actual reality has a functional, rather than an ontological nature).

Fixed rules and quantifiable outcome distinct games from play (or playfulness). In game studies, this distinction between the two terms is tied back to Roger Caillois' concept (1961) of paidia and ludus as two poles of play activities. Paidia (or playing) stands for a free-form, expressive, improvisational behavior featuring a spontaneous manifestation of the play instinct. Ludus (or gaming) implies a structured behavior characterized by explicit rule systems and competition 
towards goals or outcomes. Any games involve experiences typical of both poles; however, it is admitted that in artificially created games (including games intended for learning) the open-ended, spontaneous form of play (paidia) should be limited not to destroy the tissue of events.

The existence of feedback separates games from passive non-interactive media (emerged before the $5^{\text {th }}$ information revolution) and traditional forms of art, contributing to their appeal unbeatable even by the actual reality, though it also has feedback. However, in games, feedback is initially designed by game designers and game developers as 'juicy' ("effective, exciting, and engaging" (KAPP, 2012, p. 36)) to make their worlds extremely exciting, pulling-in and holding, to turn failures and obstacles into drivers encouraging further interaction. In the meantime, the feedback with the actual reality can rarely be inspiring; on the contrary, it tends to give lessons of caution, as any failure has a high price.

As game designer J. McGonigal (2011) laments, in contrast to the actual reality where failures are more frequently noticed than successes, the game reality is fairer: It has immediate feedback between the action and the outcome; the person feels that his accomplishment is appreciated. This prompt and positive reinforcement makes the game world competitive in relation to the real-life world.

Not for nothing, many game researchers focus on these game parameters (feedback, failures and unnecessary obstacles as challenge), which make games attractive and superior to other (conditional and actual) realities.

We will focus our attention (hence the scientific novelty of our essay) on the game characteristics - freedom, voluntary participation and non-expectation of material utility - that have been addressed tangentially so far. They are no less important.

\subsection{WORLD-OF-WORK AND WORLD-OF-PLAY}

Selflessness, voluntariness and freedom are parameters distinguishing the game (on a par with aesthetic experience ${ }^{6}$ ) from other types of activity; they characterize the world-of-play as opposed to the world-of-work and encapsulate the so-called Game Thinking, which we will discuss later on. These terms were introduced by us as a methodological principle to extend and develop ideas borrowed from social phenomenology and related to 'lifeworld' and Multiple Realities.

\footnotetext{
${ }^{6}$ in Critique of Aesthetic Judgment, I. Kant (1911) likens aesthetic experience to play as a kind of 'purposiveness without purpose.'
} 
The world-of-work includes an involuntary, compulsory activity required for survival. The world-of-play is a freely chosen, voluntary activity, which is self-appealing. On the contrary, people themselves are ready to invest their money, time and effort in it. This is self-motivated, selfrewarding, autotelic (from the Greek words for 'auto' = self, 'telos' = goal) activity: "activity rewarding in and of itself, quite apart from its end product or any extrinsic good that might result from the activity" (NAKAMURA; CSIKSZENTMIHALYI, 2002/2014, p. 240).

Games do not have any binding nature, lack of alternatives or inescapability, and this feature is the main, though not the only, explanation of their attractiveness. The soundness of this explanation is recognized by many scholars, but only few of them focus their attention on it (mainly in the context of neo-Marxism (HINMAN, 1978; ROBERTS, 2018; WRIGHT, 2018)). In their studies of the difference between a game and a non-game, scholars tend to ignore the obvious fact that the problem is rooted in the attitude towards the activity, rather than in the activity per se. This approach, by relativizing the concept of game, allows us to overcome substantialism, the extremes of which are radical autotelism and radical instrumentalism.

According to B. Suits (1978), "Radical autotelism is the view that unless games are played solely as ends in themselves, they are not really games, that is, that amateurs alone are playing games" (p. 146), and radical instrumentalism "is the view that games are essentially instruments" (p. 146), but as B. Suits (1978) admits (and I agree with him): "Such a view of games appears to be self-defeating" (p. 147).

Hard work can be present in a game: high-stakes work, busywork, mental work, physical work, discovery work, teamwork, creative work (MCGONIGAL, 2011, p. 14), however, what makes real work difficult, unpleasant, boring, and even dangerous can introduce a state of flow in a game activity.

A problem in the world-of-work turns into a challenge in the world-of-play.

Thus, it is not a matter of the activity or even its labor input, intensity, energy consumption, complexity, routine nature. On the contrary, this complexity and intensity, as distinct from passive pastime (for example, watching TV), make us feel alive: As Harvard professor and happiness expert Tal Ben-Shahar (2007) states: "We're much happier enlivening time rather than killing time." (p. 77)

As McGonigal (2011) points out, games, in contrast to the usual reality, satisfy hunger: "a hunger for more satisfying work, for a stronger sense of community, and for a more engaging and meaningful life" (p. 7). So there is nothing surprising in the paradox: In games people "are volunteering for unnecessary hard work-and they genuinely care about the outcome of their 
effort" (MCGONIGAL, 2011, p. 13), while the necessary and even quite easy work is perceived as a burden that you want to take off.

Thus, due to their belonging to the world-of-play (which is not limited to game and leisure activities, but outlines the scope of freedom and desire), games will compete with the actual reality for attention of their users as long as the above reality is associated (rightfully or not) with the worldof-work. Today, with ICT development, this rivalry tends to increase.

\subsection{FEATURES OF GAMES AND THEIR EDUCATIONAL POTENTIAL}

\subsubsection{Features of video games and their educational potential}

VR interactivity encouraging consumers' participation and involvement is seen as a distinguishing feature of video games ${ }^{7}$ as compared to other media (TV, radio, etc.) that are passive. Many video games are appealing by their 'control over the world', which is so wanted in daily life reality. The control is highly efficient and does not require any special skills or efforts. Sometimes the ability to react fast will suffice. This effect "we can call the 'amplification of input principle.' [...] In a video game, you press some buttons in the real world and a whole interactive virtual world comes to life. Amplification of input is highly motivating for learning." (GEE, 2003, p. 64).

However, the degree of freedom given to a person should not be overestimated: It is limited by choosing of one of the question/answer options or behavior strategies. Nevertheless, video games, especially action game and role-playing games, offer an opportunity not only to test one's logic abilities, to get immersed into a fantasy world, but also to adopt a new identity, pushing its boundaries to the limits impossible and unattainable in the real world.

Another important feature of video games is, "video games create what the psychologist Eric Erickson has called a psychosocial moratorium - that is, a learning space in which the learner can take risks where real-world consequences are lowered" (GEE, 2003, p. 62). This feature - the riskfree environment - has made it possible to model virtual laboratories, simulators and trainers (i.e. serious games). The safety of actions is ensured by the ontological borderline between the two worlds: the real one and the virtual one.

Thus video games (and serious games constructed on their basis) offer an opportunity not only to try on and explore a new identity, but also to test the limits of your abilities, to explore

\footnotetext{
${ }^{7}$ By 'video games' I mean both games played on game platforms and games played on computers.
} 
options and consequences of the actions that are too dangerous or physically impossible to be reproduced in the real world.

Therefore, it is easy to understand why an increasing number of people are devoting their free time to game worlds and why video games have great potential for education (TELES VIEIRA, 2020).

The first skill associated with digital leisure-time activities (for example, in arcade games and shooter games) is the development of reflexes. Improving them until they become automatic is not a primitive skill: Not for nothing, many simulators used in health care, pilot and first responder training focus on honing and mastering reflexes.

Video games also encourage pro-social behavior. But the potential of digital leisure activities is much richer. The unfolding intrigue of the captivating story rivaling fictional works of art (books and movies); prize incentives; control over the action; the opportunity to use your knowledge and abilities, your imagination and non-standard thinking; logic of overcoming obstacles; the right to fail without hazardous outcomes; the immediate, operative feedback to adapt actions; the competitive nature - all these make video games an ideal medium for learning. Not without reason, J. P. Gee (2003) pointed out 36 learning principles found in video games and suggested that adherence to these principles could transform learning in schools and universities. They are important both for learning efficiency and for learning motivation.

\subsubsection{Features of Live Action Role-Playing Games and their educational potential}

Yet, it looks like by no means all are satisfied with quite an active life in the cyber world. People look for the possibility to 'escape to another reality' through going back to the beginnings. Remember M. Bakhtin's theory about the carnival laughter culture of the Middle Ages and about its role in 'inversion of social roles'. The similar function is performed by LARPs - Live Action RolePlaying Games. They include role-playing games ${ }^{8}$ and historical reenactments. They embody a reaction to unsatisfactory roles-a passive Participant in everyday reality and an active Observer of virtual computer reality.

\footnotetext{
${ }^{8}$ on any subject, e.g. based on Fantasy literature (popular in Russia The Hobbit by J. R. R. Tolkien, The Earthsea Cycle by Ursula K. Le Guin, etc.) or computer games, for example, Dragon Age, The Elder Scrolls III: Morrowind, Warcraft, or Warhammer fantasy universe
} 
But these games function in the physical world, and therefore lack many of the advantages of video games, above all the 'amplification of input principle' and the 'psychosocial moratorium.' Therefore, it is impossible to construct computer simulators and stimulators based on LARPs.

On the other hand, it may turn into an advantage not only in enhancing machinery and equipment hands-on skills, but also in training interpersonal and teamwork skills, which is a wellestablished practice in war-games. The steady connection with the reality helps maintain a sense of real-life danger, which can dwindle and fade away in video games and simulators.

As for the educational aspect of LARPs, it involves not only individual knowledge and abilities, but also metadisciplinary competencies. Participants learn how to communicate, play roles, and get into the character. They develop visual thinking and teamwork skills. For instance, participants of a historical reenactment must as accurately as possible recreate a specific historical event; therefore, they have to study all the details of the particular period they are going to recreate. They need not only theoretical knowledge, but also practical (for example, handicraft) skills and abilities. No wonder that some of them become true experts. LARPs are highly interesting to students; however, sizeable financial, time and labor inputs keep LARPs' optional role in education.

\subsubsection{Features of Alternate Reality Games and their educational potential}

At the junction of online and offline platforms there are the so-called metagames. Alternate Reality Games (ARGs) are the best known and highly emotional type of metagames. While in video games we can see 'objectivation' of fictional and fantasy worlds, ARGs represent the opposite process: Expansion of computer games from the virtual reality into the real world.

It is the identity game that moving simulation into a new dimension outside of virtual environments gave rise to mixed-reality games - ARGs, where the world is populated by players representing real people rather than by computer-generated characters. In virtual communication and interaction with real people (their number can reach several thousand) hiding behind the masks of their virtual 'representatives', freedom of action and free will depend not only on the scenarios and scripts of producers and designers (puppet masters), but also on the collaborative efforts of players jointly creating their 'fantasy' world.

ARGs blur the line between the game space and the real-world experience. They do not make it clear where the reality ends and the game begins. Therefore, central to ARGs is the concept known as 'this is not a game' or TINAG. 
As for ARGs, they combine features of video games and social software, thus having the educational potential of both tools. Therefore, ARGs can be seen as a fascinating tool to be further used in education. Afterwards, their potential was realized in the technology of gamification.

Same as other types of games, ARGs "are designed to make it easier to generate the four intrinsic rewards we crave-more satisfying work, better hope of success, stronger social connectivity, and more meaning" (MCGONIGAL, 2011, p. 43), but unlike video games and like LARPs, - "whenever we can't or don't want to be in a virtual environment" (MCGONIGAL, 2011, p. 43).

This feature inherent in ARGs representing ontologically open conditional realities, which, as opposed to videogames, are not protected by ontological boundaries from the actual reality, makes these games less safe than video games, though less escapist. They let the players participate actively and productively both in everyday life (including daily study routine) and in game events. While video games, due to their ontological closedness, form the basis for development of serious games, ARGs, thanks to their ontological openness, form the basis for gamification.

Thus, using the example of video (digital) games, LARPs (real games) and ARGs (mixed-reality games), we gave a general picture of the educational capabilities of games.

Summarizing all the above, we can outline the main advantages of games in education, regardless of their platforms (online, offline and their combination).

\subsection{GAMES AND LEARNING: RESULT OF REFLECTION}

The most educationally attractive quality of games is their ability to have the power to engage, inform, and educate. The following game features serve this purpose: The game is the most natural way of receiving information. Game participants can use and creatively process information; collaboration increases their involvement and their interest in a particular subject. The opportunity to choose different strategies and roles is a strong motivating factor. The willingness to take part in the game results in very high replayability. Repetitive, recurring, identical moments (boring in any other non-game context) become much more interesting and naturally perceived. Thus, the ability can gradually turn into a skill. It is especially important in the context of a competency-based approach to education (VAGANOVA et al., 2020). And also, the game helps to achieve the synthesis of disciplines. Most importantly, the game makes the learning process unnoticeable and gradual. These basic features make games different from traditional (frontal) teaching and turn them into highly efficient educational tools. 
As an intermediate conclusion, we can note that the initial opposition between learning and game stems from the difference between utilitarian and hedonic activities. "Play is perceived as an activity having little to do with daily life strains and duties; on the contrary, it offers an escape from them" (GILYAZOVA; ZAMOSHCHANSKII, 2020, p. 49). On the other hand, it is believed that addition of hedonic elements such as game elements to a utilitarian activity can create enjoyment and involvement inherent in play activities. It is achieved with the technology of gamification, which "combines both hedonic and utilitarian values in a new kind of motivational aggregate." (DICHEVA et al., 2019, p. 6). It is gamification that acts as one of the ways to overcome the dichotomy between the world-of-work and the world-of-play through a harmonious combination of educational and gaming elements.

\section{GAMIFICATION AND LEARNING}

\subsection{THE CONCEPT OF GAMIFICATION}

Gamification is a relatively new concept. The term 'gamification' in its present-day meaning gained widespread usage in 2010 (ÇEKER; ÖZDAMLI, 2017). The concise and compact definition of gamification is the most frequently mentioned one in literature: "Gamification is the use of game design elements in non-game contexts." (DETERDING et al., 2011, p. 10).

The fact that educational practitioners and theorists favor Deterding's definition is easy to explain: Gamification designed in conformity with this definition is easy to implement. That is why this type of gamification is most commonly used. "In fact, three main components of gamification framework 'points, leaderboards and badges' have already been implemented in the educational process: scoring system, student's ratings and personified scholarships." (ALGAVI et al., 2017, p. 66).

In Russian universities, the Point Rating System (PRS) is a classic gamification system. Being simple and easy to demonstrate, this system is used countrywide. On the other hand, the PRS hinders promotion of more sophisticated and motivating types of gamification. One system overlaps the other and both of them start interfering with each other. Students get confused, failing to understand which gamification system is the primary one; their attention and motivation start vanishing.

The problem is that the narrow understanding of gamification puts emphasis on game mechanics elements ('points, badges and leaderboards'), which are important as building blocks and constitute only a part of gamification. Also, a lot of attention is given to aesthetics (engaging 
graphics) of gamification. In the meantime, the disregard of its other elements such as Game-Based (the concepts outlined in the definition of 'game' described above apply to gamification) degrades gamification. For this reason, K. Kapp offers a much broader interpretation of gamification. "Gamification is using game-based mechanics, aesthetics and game thinking to engage people, motivate action, promote learning, and solve problems" (KAPP, 2012, p. 10).

All elements are important in this definition. However, the most important element of gamification, in K. Kapp's opinion (2012), is Game Thinking, i.e. the ability to present a boring duty in the form of an interesting activity, in which people want to invest brain share, time, and energy. It is Game Thinking that is responsible for converting job-related problems and obstacles into challenges and fun in the game. An example of this thinking is Tom Sawyer's trickery, when he took advantage

a great law of human action [...] namely, that in order to make a man or a boy covet a thing, it is only necessary to make the thing difficult to attain. [...] Work consists of whatever a body is OBLIGED to do, and that Play consists of whatever a body is not obliged to do. (TWAIN, 1876/no date, p. 19).

As we can see, the fact that the same activity can be perceived either as play or as work, depending on the way it is presented (as a voluntary or mandated activity) was intuitively understood by Tom Sawyer who tricked his friends into whitewashing the fence for him. Gamification of education is intended to change the modality of a learning activity, presenting it (but not turning! - this is important, we will explain further) as a game (enjoyment) rather than work (duty). Indeed, gamification is aimed at replication of Tom Sawyer's success.

This approach to gamification helps to understand why K. Kapp does not see it as a new phenomenon. His opinion is shared by Brian Burke. Teachers, coaches and military people have been using gamification elements in their activity for centuries. The innovativeness is rooted in conceptualization and systematization of their best practices in response to digitalization of the environment.

The above approach to gamification seems to be more effective than the narrower approach offered by S. Deterding et al., though K. Kapp's approach is not free from shortcomings, where difficulty of implementation is topping the list. 


\section{2 ‘GAMIFICATION’ AND ‘GAMES’: DIFFERENTIATION OF CONCEPTS}

The primarily digital (more precisely, transmedial) nature of gamification makes it different from usual 'real' games and turns it into an innovative phenomenon: "What's new about gamification is that it uses a digital model to extend engagement and motivation beyond face-toface interactions, breaking the barriers of scale, time, distance, connectedness, and cost" (BURKE, 2014, p. 39).

However, gamification should not be confused not only with standard real games, but also with digital and mixed-reality games. Although any game and gamification are inseparably intertwined, these concepts (phenomena) should be differentiated. The fundamental difference between the game and gamification can be found in their purposes. While for games, entertainment is a primary purpose, in gamification it is merely a tool. It implies application of a digital content making it possible to combine utilitarian and hedonic elements with the intention to provide longterm and sustainable education rather than entertainment as such ${ }^{9}$.

Due to the difference between games and gamification (the entertainment nature of the former and the dual nature of the latter), games ${ }^{10}$ are selected for preschool and elementary school education, while gamification is a preferred choice at middle schools, high schools and especially at universities.

Let's look at the difference between gamification and serious games. Serious games, as well as gamification, function for non-entertainment purposes, and it is how they differ from usual entertainment games. But both serious games and entertainment games are full-fledged games. In this aspect, they are like each other and are distinguished from gamification. The thing is that the game is a space and time-constrained conditional reality, "a self-contained unit" (KAPP et al., 2013, p. 95), "while gamification is an educational tool, which creates a shell for the reality we live but itself (unlike the game) is not separate reality" (GILYAZOVA; ZAMOSHCHANSKII, 2020, p. 45). 'Gamification' merely incorporates elements of games, not a full 'game proper', therefore gamification and any full-fledged games can be differentiated through the part/whole dimension.

\footnotetext{
9 There is difference between 'gamification' and 'edutainment' (the combination of 'education' and 'entertainment'). As the terminology is still not well-established, these concepts are frequently perceived as synonyms. Edutainment means 'education as/through entertainment' and it intersects with the concept of gamification. Gamification is built mainly on a digital platform, while edutainment is not limited to it.

${ }^{10}$ In practice, games can have unexpected pedagogical components, which initially were totally unforeseen by game creators. Therefore, the educational potential of games, even when used unwittingly, should not be ignored. Even games created solely for entertainment and amusement can serve as tools of informal education.
} 
Let's turn to a short and succinct description of differences between games, rewards programs, gamification and serious games:

Games primarily engage players on a whimsical level to entertain them.

Rewards programs primarily engage players on a transactional level to compensate them.

Gamification engages players on an emotional level ${ }^{11}$ to motivate them. (BURKE, 2014, p. 31)

Serious games engage players on a controlled-risk level to practice them.

Accordingly, there are five basic currencies that players accumulate in game economies: "Fun is the primary currency of games. Things are the primary currency of rewards programs. Self-esteem and social capital are the primary rewards of gamified solutions." (BURKE, 2014, p. 31). Skills are the currency of serious games.

Let's compare gamification with the types of games we discussed earlier: "In contrast to video games, most gamified solutions do not have elaborate virtual worlds with high-quality animation, simulations, and avatars" (BURKE, 2014, p. 99). Considering that "Gamification is a method to digitally engage" (BURKE, 2014, p. 13), it does not coincide with LARPs, which are limited to personally engage. Thus, ARGs is the only type of game that can be confused with gamification, due to their ontological similarity. For clarity, let's look at this fact in the example offered by J. McGonigal. She describes Chore Wars ('chore management system') as ARG. Chore Wars is "essentially a simplified version of World of Warcraft, with one notable exception: all of the online quests correspond with real-world cleaning tasks." (MCGONIGAL, 2011, p. 42).

In fact, what we see here is gamification rather than an ARG. What is the difference? The difference is in the activity that belongs either to the world-of-work (then, we deal with gamification) or to the world-of-play (in which case we have an ARG). However, housework, no matter how enjoyable and entertaining it can be (via the experience points and virtual gold, etc.), is always compulsory. We may do it more often or more rarely, meticulously or carelessly, but we cannot stop doing it. Yet, if there are domestic servants or household members who are ready to shoulder household chores, the housework will become voluntary and, thus, belonging to the worldof-play. Then, the participation in Chore Wars (obviously, not for servants) will turn into an ARG ${ }^{12}$.

\footnotetext{
${ }^{11}$ In our terminology, transactional engagement is based on the world-of-work and emotional engagement is based on the world-of-play.

12 I think that J. McGonigal, who emphasizes the crucial significance of voluntary participation as an essential characteristic of the game, would accept this differentiation and would label her example as gamification rather than a game. The reason for her not mentioning gamification is that by the time her book had been published (2011) the term just started being used by scholars and still needed a clear definition.
} 
Thus, despite their similarities, games and gamification are different activities: While a game is built on the opposition between the world-of-work and the world-of-play, gamification is aimed at its elimination. This explains why specialists in gamification of learning speak about presenting learning as a game, without turning it into a game.

\section{THE OPPORTUNITIES AND WEAKNESSES OF GAME-BASED AND GAMIFIED EDUCATION}

Earlier, we looked at the educational potential of video games, LARPs, and ARGs. There are opportunities offered by gamification. They are inherited from games. Therefore, it is worth considering the opportunities of game-based and gamified education in general. However, they are fraught with material weaknesses. Let's look at them in more detail.

B. Dyakonov (2016) notes that the previous stage of education was characterized by a 'punitive' approach, which implies that learning is associated with diligence and hard work inspired by fear of punishment for poor grades, while the modern education incorporating game and gamification technology goes away from serious academic teaching, minimizing 'negative associations.' However, B. Dyakonov's concerns about game-based and gamified education and its departure from serious academic teaching are not quite justified.

Games and gamification do not imply trivialization and simplification of learning.

Gamification is not a cheapening or dilution of 'real learning' [...] Gamified learning can, and is, difficult, challenging, and stressful. Well-designed games help learners acquire skills, knowledge, and abilities in short, concentrated periods of time with high retention rates and effective recall. (KAPP, 2012, p. 13).

But game-based and gamified learning should not be perceived as a panacea or a framework for the entire system of education otherwise the illusion will be formed that learning should always be, if not easy, then enjoyable, entertaining and thrilling.

Is pleasure of learning always justified? If learning involves search and retaining of large amounts of information with no efforts other than rote memorization, entertainment approach can be welcomed; however, if learning involves developing strong-willed skills and abilities, its sweetening will have an adverse effect.

Learning, like athlete training, involves the ability to overcome oneself, one's reluctance, laziness or unwillingness without any external rewards and internal incentives. This constitutes the educational role of learning, which frequently is more important in life than acquiring tons of information that becomes outdated quickly in our environment of rapid change. 
There is another angle to this problem. Education (including higher education) cab be artificially shrunk only from one side by minimizing everything belonging to the world-of-work and maximizing the world-of-play. Although elements of the world-of-work cannot be removed completely from the learning process and educational environment, they can be disguised in the gloss of game mechanics or game thinking. No wonder some education innovators, such as Prensky, believe that the ideal school ${ }^{13}$ doesn't use games to teach students, but the ideal school is a game, from start to finish (MCGONIGAL, 2011, p. 45).

But the role of the school is not only to provide education (even in the most pleasant way), but also to be an agent of socialization. The school must prepare students for life that can be not only smooth, but also rough; not only exciting, but also boring; not only thrilling, but also humdrum, where they will have to deal not only with constructive distresses, but also destructive stresses; not only delightful emotions, but also onerous duties; not only recoverable, but also irreparable or even fateful mistakes.

Gaming learning advantage is that it makes it easier to correct mistakes as compared with traditional education: The system (depending on its settings) allows participants to learn from their mistakes through unlimited do-overs. But on the other hand, this approach (in contrast to the former 'punitive' approach) can involuntarily teach students to perceive and treat the world-ofwork and everything that is associated with it in a similar fashion with the world-of-play. The problem is that

such 'do-over' attitude can be adopted toward real life (undermining the feeling of responsibility). Life is not a game, and consequences of mistakes cannot be ignored [...] It is important to be able to correct mistakes in life rather than in a game where they can be corrected through selection of options. (EMELYANENKO, 2018, p. 139 , my translation).

Adoption of game-based and gamified education has another aspect: Being tired of gaming or gamifying practices at school, students will lose their love for actual games and other nonutilitarian recreational activities constituting the world-of-play. Games will no longer be appreciated (due to suspected manipulations) for freedom, spontaneity, sheer pleasure and amusement, i.e. for what makes games so appealing. J. McGonigal (2011) recommends: "Wherever there is a mandatory experience that is unpleasant or frustrating, a surefire way to improve it is to design a good game you can only play in that space." (p. 52). But she forgets that this improvement of the mandatory

\footnotetext{
${ }^{13}$ There are examples of attempts to implement this ideal in life: Quest to Learn (Institute of Play project), public charter school, New York City, USA; New school 'Yna', private school, Dubna, Moscow region, Russia
} 
experience can poison the game's initially enjoyable experience. Sugar is pleasant by itself, but it will evoke negative associations, if it is continuously used to sweeten disgusting medicine. Similarly, the world-of-play will be damaged by attempts to use its resources to sweeten the world-of-work. ${ }^{14}$

Another significant aspect should be pointed out: The non-compulsory activity, unlike the compulsory one, must be extremely involving, even addictive, otherwise its main advantages freedom and voluntary participation will result in loss of interest or even refusal to participate. It is true that the world-of-play is built on intrinsic motivation and, thus, surpasses the world-of-work, which needs extrinsic motivation. However, the intrinsic motivation must be so deep and extreme that it may result in a breakdown if maintained for a long time. In this sense, the world-of-play significantly loses out to the world-of-work with its shallow, but permanent motivation ${ }^{15}$.

This feature is inherent in any games and game technologies but is especially relevant for gamification. In this sense, gamification is highly efficient in the short term. As Andrey Komissarov (2020) warns, the problem is that gamification has peak activity. With all its unquestionable advantages, gamification is a rather sophisticated and sensitive tool: It is easy to overshoot the mark in it. It means that if gamification is too involving or too long-lasting, the students will not want to switch back to their routine activity without it. At the same time, they will also get tired of the gamification. There will be a forked road situation: We can increase the intensity of emotions and offer new, more penetrating gamification; then everything will continue till the time it again becomes annoying. Alternatively, we can go back to our routine activities without gamification. But if gamification lasted long and

was highly involving, the students may experience withdrawal syndrome, which can result in decreased efficiency of education and even in the loss of the effect previously typical of usual (without gamification) classes. It is the main drawback and the main threat specific to gamification (GILYAZOVA; ZAMOSHCHANSKII, 2020, p. 48).

Thus, we can state that even full-featured game-based methods and gamified technologies are not perfect for every learning situation.

\footnotetext{
${ }^{14}$ While paying a lot of attention to risks (termed the hidden costs of reward or the overjustification effect) associated with attempts to improve what is already enjoyable by adding external rewards (first of all, money), scholars tend to ignore negative consequences of attempts to sweeten the world-of-work by using resources of the world-of-play. While gamification presents (not transforms!) the world-of-work as the world-of-play, the overjustification effect signifies transformation of the world-of-play into the world-of-work.

${ }^{15}$ In fact, the same is said by Yu-kai Chou (2016), who points to the weakness of 'White Hat Gamification' (focused on the aspects of activity, which we assigned to the world-of-play) compared to the 'Black Hat' (in many respects compatible with the world-of-work). The world-of-play is extremely demanding to those who want to see it as Aristotle's 'noble leisure' rather than as 'thrilling' entertainment or careless, mind-numbing and passive pastime.
} 
Too often the learning profession embraces a new concept as the answer to all learning problems and overhypes the concept to the point of backlash. [...] If gamification is seen as a panacea and applied to every single learning event, it will quickly become trivialized and non-impactful. (KAPP, 2012, p. 14).

\section{CONCLUSION}

In conclusion, we can say that many of the shortcomings inherent in game-based and gamified education, including those of them that we have discussed in our article, stem not so much from imperfection of the technology (such as gamification) as from the fact that it is seen as universal remedy for students' artificial engagement in the activity, in which, otherwise, they would not participate.

In this sense, the functionality of gaming practices and technologies has natural limits: They can have an effect on students only as an aperitif, which stimulates the appetite, rather than as a spice, which can help in selling poor-quality food. Cynical hopes that they can be used for manipulation of people and they will not notice it - to a great extent are responsible for disappointment in them.

\section{REFERENCES}

ALGAVI, Leila; DESYAEVA, Natalia; KILPELYAYNEN, Evgenia; VOLKOVA, Irina. Gamification in Education: Boss Fight. In: LO, Sing Kai (Ed.). EEIA2017 Proceedings. Moscow: Russian Acad. Educ., 2017, v. 28, p. 61-69. DOI: 10.15405/epsbs.2017.08.8.

BEN-SHAHAR, Tal. Happier: Learn the Secrets to Daily Joy and Lasting Fulfillment. New York: McGraw-Hill, 2007.

BUKHTOYAROV, Mikhail; KOZLOVA, Maria. Gamification of teaching philosophy on the example of the game 'Philosophical hunt'. Filosofiya Obrazovaniya - Philosophy of Education, v. 77, n. 4, p. 128-137, 2018. DOI: 10.15372/PHE20180412

BURKE, Brian. GAMIFY: How Gamification Motivates People to do Extraordinary Things. EUA: Gartner, Inc., 2014.

BRITO, C. D. A. S.; NUNES, C. P. The intensification of teaching work in the context of the commercialization of higher education in Brazil. Journal of Research and Knowledge Spreading, v. 1, n. 1, p. 1-17, 2020.

CAILLOIS, Roger. Man, Play and Games. Trans. by Meyer Barash. New York: Free Press of Glencoe, 1961. 
ÇEKER, Eser; ÖZDAMLI, Fezile. What 'gamification' is and what it's not. European Journal of Contemporary Education, v. 6, n. 2, p. 221-228, 2017. DOI: 10.13187/ejced.2017.2.221

CHOU, Yu-kai. Actionable Gamification: Beyond Points, Badges and Leaderboards. Lean Publishing, 2016. Available at: http://leanpub.com/actionable-gamification-beyond-points-badgesleaderboards. Accessed date: 17 August 2020.

CSIKSZENTMIHALYI, Mihaly. Play and Intrinsic Rewards. In: CSIKSZENTMIHALYI, Mihaly (Author). Flow and the Foundations of Positive Psychology. Chapter 10. Springer, Dordrecht, p. 138-153, $1975 / 2014$.

DETERDING, Sebastian; DIXON, Dan; KHALED, Rilla; NACKE, Lennart. From game design elements to gamefulness: Defining 'gamification'. In: LUGMAYR, Artur; FRANSSILA, Heljä; SAFRAN, Christian; HAMMOUDA, Imed (Eds.). MindTrek '11 Proceedings. Tampere: Academic MindTrek, 2011, p. 915.

Dias, Alfrancio Ferreira. Trans* escrevivências as a pedagogical power. Journal of Research and Knowledge Spreading, v. 1, n. 1, p. 1-17, 2020.

DICHEVA, Darina; IRWIN, Keith; DICHEV, Christo. Exploring Learners Experience of Gamified Practicing: For Learning or for Fun? International Journal of Serious Games, v. 6, is. 3, p. 5-21, September, 2019. DOI: 10.17083/ijsg.v6i3.299

DYAKONOV, Boris. Gamification in asynchronous education process. Istoricheskaya i sotsial'noobrazovatelnaya mys'I - Historical and Social Educational Ideas, v. 8, n. 1/1, p. 143-147, 2016. DOI: 10.17748/2075-9908-2016-8-1/1-143-147

EMELYANENKO, Vladimir. Gamification in education: the limits of application (values and worldview approach). Filosofiya Obrazovaniya - Philosophy of Education, v. 75, n. 2, p. 130-146, 2018. DOI: 10.15372/PHE20180211

GEE, James Paul. What Video Games have to teach us about learning and literacy. EUA: Palgrave Macmillan, 2003.

GILYAZOVA, Olga; ZAMOSHCHANSKII, Ivan. On motivational tools of gamification in higher education: theoretical aspect. Perspektivy nauki i obrazovania - Perspectives of Science and Education, v. 45, n. 3, p. 39-51, 2020. DOI: 10.32744/pse.2020.3.3

HINMAN, Lawrence. Marx's Theory of Play, Leisure, and Un-Alienated Praxis. Philosophy and Social Criticism, v. 5, p. 192-228, 1978.

HECKLER, Valmir. et al. Investigation with experimental practical activities in training geographically distant teachers. Journal of Research and Knowledge Spreading, v. 1, n. 1, p. 1-15, 2020.

HUIZINGA, Johan. Homo Ludens: A Study of the Play-Element in Culture. London: Routledge \& Kegan Paul, 1949.

KAPP, Karl; BLAIR, Lucas; MESCH, Rich. The Gamification of Learning and Instruction Fieldbook: Ideas into Practice. EUA: John Wiley \& Sons, 2013. 
KAPP, Karl. The Gamification of Learning and Instruction: Game-Based Methods and Strategies for Training and Education. San Francisco: John Wiley \& Sons, 2012.

KANT, Immanuel. Critique of Aesthetic Judgement. Trans. by James Creed Meredith. Oxford: Clarendon press, 1911.

KOMISSAROV, Andrey. Game practices in education, 2020. Available at:

https://openedu.ru/course/misis/IGRO/. Accessed date: 17 August 2020.

MCGONIGAL, Jane. Reality is broken - Why games make us better and how they can change the world. New York: Penguin Books, 2011.

NAKAMURA, Jeanne; CSIKSZENTMIHALYI, Mihaly. The Concept of Flow. In: CSIKSZENTMIHALYI, Mihaly (Author). Flow and the Foundations of Positive Psychology. Chapter 16. Springer, Dordrechtpp, p. 239-263, 2002/2014.

PINTO, E.J.S.; CARVALHO, M. E. P.; RABAY, G. As relações de gênero nas escolhas de cursos superiores. Revista Tempos e Espaços em Educação, v. 10, n. 22, p. 47-58, 2017.

PRENSKY, Marc. Engage me or enrage me: What today's learners demand. Educause Review, $v$. 40, n. 5, p. 60-65, 2005. Available at: https://er.educause.edu/articles/2005/1/engage-me-orenrage-me-what-todays-learners-demand Accessed date: 17 August 2020.

ROBERTS, Michael. The Politics of Playtime: Reading Marx through Huizinga on the Desire to Escape from Ordinary Life. American Journal of Play, v. 11, n. 1, p. 46-64, 2018.

SHUTALEVA, Anna; KERIMOV, Alexander; TSIPLAKOVA, Yulia. Humanization of education in digital era. Perspektivy nauki i obrazovania - Perspectives of Science and Education, v. 42, n. 6, p. 3143, 2019. DOI: 10.32744/pse.2019.6.3

SUITS, Bernard. The Grasshopper: Games, Life and Utopia. Toronto, Buffalo, London: University of Toronto Press Broadview Press, 1978.

TELES VIEIRA, Andreia. To play or not to play, that is the question! In: GÓMEZ CHOVA, Louis; LÓPEZ-MARTÍNEZ, Alejandro; CANDEL TORRES, Isabel (Eds.). EDULEARN20 Proceedings. Valencia: IATED Academy, 2020, p. 7839-7846. DOI: 10.21125/edulearn.2020.1977.

TWAIN, Mark. The Adventures of Tom Sawyer. Free eBooks at Planet eBook.com, 1876/no date. Available at: https://www.planetebook.com/free-ebooks/the-adventures-of-tom-sawyer.pdf Accessed date: 17 August 2020.

VAGANOVA, Olga; TSYGANOVA, Larisa; CHELNOKOVA, Elena; LAPSHOVA, Anna; REDKINA, Lyudmila. Socio-gaming technology in the development of students' personality. Amazonia Investiga, v. 9, n. 29, p. 69-76, 2020. DOI: 10.34069/AI/2020.29.05.9

WRIGHT, J. Talmadge. Liberating Human Expression: Work and Play or Work versus Play. American Journal of Play, v. 11, n. 1, p. 3-25, 2018. 


\section{ABOUT THE AUTHOR}

\section{Olga Gilyazova}

PhD in Philosophy, Center for the Development of Universal Competencies, Ural Federal University named after the First President of Russia B. N. Yeltsin, Ekaterinburg, Russia.

E-mail: olga gilyazova@mail.ru

ORCID: https://orcid.org/0000-0002-6978-1162 